\title{
Patient perception of recovery following severe trauma: experience from a trauma follow-up clinic
}

\author{
Anita West ${ }^{*}$, Karen Hoffman ${ }^{2}$ \\ From London Trauma Conference 2013 \\ London, UK. 10-13 December 2013
}

\section{Background}

Appropriate follow-up for survivors of trauma and their family is important. However, many clinician led followup clinics focus on single systems of injury rather than the overall recovery of the patient. This study examined patient perception of outcome following multiple injuries at a Major Trauma Centre.

\section{Methods}

A prospective cohort study was conducted on trauma patients admitted to a Major Trauma Centre for more than 72 hours. A proportion of these patients were seen in a trauma follow-up clinic approximately two months post injury. Semi structured interviews were conducted during clinic appointments. The World Health Organisation International Classification of Function Disability and Health (WHO ICF) was used as a framework to structure questions relating to recovery. Descriptive data analysis was completed.

\section{Results}

Two hundred and ninety seven patients were recruited with a median ISS of 13 . The median age was 29 years and $57 \%$ of patients suffered penetrating trauma. There was a difference in the type of problems reported between blunt and penetrating trauma patients. Seventy percent of patients reported pain and mental health as limitations to recovery. Additional participation restrictions, such as environmental barriers, fatigue and return to work were highlighted as problematic.

'Barts Health NHS Trust, Royal London Hospital, Trauma Unit, Whitechapel, London, E1 1BB, UK

Full list of author information is available at the end of the article

\section{Conclusions}

The ICF was a useful framework to capture a vast range of health components during a follow-up clinic attendance. It was able to describe the differences in patient populations. Interviews emphasised the complex psychosocial needs of trauma patients in an urban setting.

\section{Authors' details}

'Barts Health NHS Trust, Royal London Hospital, Trauma Unit, Whitechapel, London, E1 1BB, UK. ${ }^{2}$ Queen Mary University London, Blizard Institute, 4 Newark Street, London E1 2AT, UK.

Published: 7 July 2014

doi:10.1186/1757-7241-22-S1-P11

Cite this article as: West and Hoffman: Patient perception of recovery following severe trauma: experience from a trauma follow-up clinic. Scandinavian Journal of Trauma, Resuscitation and Emergency Medicine 2014 22(Suppl 1):P11.
Submit your next manuscript to BioMed Central and take full advantage of:

- Convenient online submission

- Thorough peer review

- No space constraints or color figure charges

- Immediate publication on acceptance

- Inclusion in PubMed, CAS, Scopus and Google Scholar

- Research which is freely available for redistribution

Submit your manuscript at www.biomedcentral.com/submit
( Biomed Central 